\title{
Oxidative Stress Alters miRNA and Gene Expression Profiles in Villous First Trimester Trophoblasts
}

\author{
Courtney E. Cross, ${ }^{1}$ Mai F. Tolba, ${ }^{2}$ Catherine M. Rondelli, ${ }^{1}$ \\ Meixiang $\mathrm{Xu}$, ${ }^{1}$ and Sherif $\mathrm{Z}$. Abdel-Rahman ${ }^{1}$ \\ ${ }^{1}$ Department of Obstetrics and Gynecology, The University of Texas Medical Branch, Galveston, TX 77555-1066, USA \\ ${ }^{2}$ Department of Pharmacology and Toxicology, Faculty of Pharmacy, Ain Shams University, Cairo 11566, Egypt \\ Correspondence should be addressed to Sherif Z. Abdel-Rahman; sabdelra@utmb.edu
}

Received 10 December 2014; Revised 13 March 2015; Accepted 20 March 2015

Academic Editor: Luciana dos Reis Vasques

Copyright ( $\odot 2015$ Courtney E. Cross et al. This is an open access article distributed under the Creative Commons Attribution License, which permits unrestricted use, distribution, and reproduction in any medium, provided the original work is properly cited.

\begin{abstract}
The relationship between oxidative stress and miRNA changes in placenta as a potential mechanism involved in preeclampsia (PE) is not fully elucidated. We investigated the impact of oxidative stress on miRNAs and mRNA expression profiles of genes associated with $\mathrm{PE}$ in villous $3 \mathrm{~A}$ first trimester trophoblast cells exposed to $\mathrm{H}_{2} \mathrm{O}_{2}$ at 12 different concentrations $(0-1 \mathrm{mM})$ for $0.5,4,24$, and $48 \mathrm{~h}$. Cytotoxicity, determined using the SRB assay, was used to calculate the $\mathrm{IC}_{50}$ of $\mathrm{H}_{2} \mathrm{O}_{2}$. RNA was extracted after $4 \mathrm{~h}$ exposure to $\mathrm{H}_{2} \mathrm{O}_{2}$ for miRNA and gene expression profiling. $\mathrm{H}_{2} \mathrm{O}_{2}$ exerted a concentration- and time-dependent cytotoxicity on $3 \mathrm{~A}$ trophoblast cells. Short-term exposure of $3 \mathrm{~A}$ cells to low concentration of $\mathrm{H}_{2} \mathrm{O}_{2}\left(5 \%\right.$ of $\left.\mathrm{IC}_{50}\right)$ significantly altered miRNA profile as evidenced by significant changes in 195 out of 595 evaluable miRNAs. Tool for annotations of microRNAs (TAM) analysis indicated that these altered miRNAs fall into 43 clusters and 34 families, with 41 functions identified. Exposure to $\mathrm{H}_{2} \mathrm{O}_{2}$ altered mRNA expression of 22 out of 84 key genes involved in dysregulation of placental development. In conclusion, short-term exposure of villous first trimester trophoblasts to low concentrations of $\mathrm{H}_{2} \mathrm{O}_{2}$ significantly alters miRNA profile and expression of genes implicated in placental development.
\end{abstract}

\section{Introduction}

Preeclampsia (PE), which affects $3 \%$ to $8 \%$ of pregnant women, remains a major cause of short- and long-term maternal and neonatal morbidity and mortality. It is a medical condition characterized by de novo hypertension in pregnancy (diastolic $>90 \mathrm{~mm} \mathrm{Hg}$ ) after 20-week gestation with high proteinuria $(>300 \mathrm{mg})$ [1]. PE is thought to result from a combination of many factors including shallow trophoblast invasion, failed maternal spiral artery remodeling, and an increase in endothelial activation leading to placental hypoxia, reactive oxygen species (ROS) generation, apoptosis and necrosis of trophoblasts, and systemic activation of inflammatory processes in the mother [1]. Superoxide anions generated endogenously or exogenously can rapidly be converted to hydrogen peroxide $\left(\mathrm{H}_{2} \mathrm{O}_{2}\right)$ [2] and studies showed a significant elevation of $\mathrm{H}_{2} \mathrm{O}_{2}$ levels in the bloodstream of women with PE [3,
4]. $\mathrm{H}_{2} \mathrm{O}_{2}$ levels are also significantly higher in preeclamptic placentas compared to normotensive placentas at term [5]. Moreover, evidence supports an early increase in oxidative stress in the placenta by the end of the first trimester before the clinical development of PE [6-8]. Oxidative stress can induce endothelial dysfunction and vasoconstriction [9]. Therefore, the relationship between oxidative stress and PE is a vicious cycle where increased oxidative stress can induce PE and the occurrence of $\mathrm{PE}$ also exacerbates oxidative stress. The age-adjusted incidence of $\mathrm{PE}$ in the United States increased almost 25\% from 1987 to 2004 [10]. With disease risk on the rise but no effective way to predict its development, it is crucial to understand the early etiologic mechanisms of PE to develop early detection biomarkers and possible preventive measures for the disease.

MicroRNAs (miRNAs) are short 20-22 single strand regulatory RNAs that function by inhibiting translation of their 
targets or promoting target RNA degradation $[11,12]$. There is a temporal and placental-specific pattern of miRNA expression [13]. This pattern includes two large imprinted miRNA clusters, one located at chromosome 19q13.41 (C19MC) and another at 14q32 (C14MC). Expression of C14MC decreases while expression of C19MC increases as pregnancy progresses [14]. Women with PE, eclampsia, and HELLP (Hemolysis, Elevated Liver enzymes, Low Platelets) syndrome have significant alterations in the placental miRNA profile. For example, dysregulation of C19MC expression is seen in preeclamptic placentas [15]. In addition, miR-210, which regulates hypoxiainducible factor 1, is commonly found to be upregulated in PE women [16]. Dysregulated expression of a number of other miRNAs, such as the oncogenic miR-17 family, occurs in preeclamptic placentas but the temporal change is unknown [17-20]. Given the reported changes in miRNAs observed in $\mathrm{PE}$, early detection, protection, and regulation of miRNAs may help decrease the impact of this disease.

The relationship between oxidative stress and miRNA changes in placenta as a potential mechanism involved in $\mathrm{PE}$ is not fully elucidated. In the present study, we investigate the impact of oxidative stress on miRNA and mRNA expression profiles, with specific emphasis on mRNAs of genes known to be associated with $\mathrm{PE}$, in villous first trimester 3A cytotrophoblast cell line.

\section{Materials and Methods}

2.1. Chemicals and Reagents. The villous $3 \mathrm{~A}$ cytotrophoblast first trimester placental cell line (CRL-1584) was purchased from American Type Culture Collection (ATCC) (Manassas, VA). The miRNA and mRNA kits with appropriate realtime reagents and miRNEasy were purchased from Qiagen (Valencia, CA). CytoScan SRB cell cytotoxicity assay kit was purchased from G-biosciences (St. Louis, MO). Eagle's Minimum Essential Medium (EMEM) and 0.25\% trypsin were Gibco brand (Life technologies, Grand Island, NY). Fetal bovine serum (FBS) was acquired from Atlanta Biologicals (Lawrenceville, GA). All other chemicals were purchased from Sigma-Aldrich Co. (St. Louis, MO, USA) and were of the highest purity available.

2.2. Cell Culture and $\mathrm{H}_{2} \mathrm{O}_{2}$ Treatment. Villous 3A cytotrophoblast cells were maintained in $75 \mathrm{~cm}^{2}$ flasks at $37^{\circ} \mathrm{C} / 5 \%$ $\mathrm{CO}_{2}$ in complete medium consisting of EMEM supplemented with $10 \%$ fetal bovine serum and $1 \%$ penicillin/streptomycin. Cells were passaged at $\sim 90 \%$ confluency. $\mathrm{H}_{2} \mathrm{O}_{2}$ exposures were performed in complete medium for the times and concentrations specified in a humidified incubator at $37^{\circ} \mathrm{C}$ supplemented with $5 \% \mathrm{CO}_{2}$.

2.3. Determination of $\mathrm{H}_{2} \mathrm{O}_{2} \mathrm{IC}_{50}$. Cells were seeded in 12 -well plates at a density of $0.25 \times 10^{5}$ cells/well and were allowed to attach for 24 hours. Growth media were replaced either with fresh media for mock exposure or with one of 12 different concentrations of $\mathrm{H}_{2} \mathrm{O}_{2}$ ( 0 to $\left.1 \mathrm{mM}\right)$ in complete medium for 0.5 , 4,24 , or $48 \mathrm{~h}$ without further media replacement. Cytotoxicity was assessed at the end of $\mathrm{H}_{2} \mathrm{O}_{2}$ exposure using the SRB assay as previously described [21]. Briefly, after exposure, cells were fixed with $10 \%$ tricholoroacetic acid for one hour and then stained with $0.4 \%$ SRB dissolved in $1 \%$ acetic acid. Excess dye was washed and wells were air-dried. Bound dye was solubilized in $10 \mathrm{mM}$ Tris ( $\mathrm{pH}$ 7.4) and absorbance was measured at $560 \mathrm{~nm}$ using a microplate reader (TECAN GENios Pro, Männedorf, Switzerland). Results were expressed as the relative percentage of absorbance compared to control. All experiments were performed in triplicate. Half-maximal inhibitory concentration $\left(\mathrm{IC}_{50}\right)$ was calculated using SigmaPlot, version 12.3 (Systat Software Inc., San Jose, CA, USA).

2.4. Assessment of Oxidative Stress Markers. Reduced glutathione (GSH) levels and superoxide dismutase (SOD) activity were assessed in the cell lysates as markers for oxidative stress $[22,23]$. To determine the level of GSH, an aliquot $(0.2 \mathrm{~mL})$ of cell lysate was added to a tube containing $1.7 \mathrm{~mL}$ phosphate buffer and $0.1 \mathrm{~mL}$ Ellman's reagent; then the absorbance was read at $412 \mathrm{~nm}$ within $5 \mathrm{~min}$ [24]. The results were expressed as $\mathrm{mg} / \mu \mathrm{g}$ protein. SOD activity was assessed in the cell lysates using an assay that relies on the ability of SOD enzyme to inhibit the phenazine methosulphate(PMS-) mediated reduction of nitroblue tetrazolium dye. The change in absorbance over $5 \mathrm{~min}$ was measured at $560 \mathrm{~nm}$ [25]. SOD activity was expressed as U/mg protein. Protein levels were determined using the BCA protein assay (Pierce Biotechnology, Rockford, IL, USA). Student's $t$-test was used for statistical comparisons and significant differences were established at $P<0.05$.

2.5. Determination of Effects of $\mathrm{H}_{2} \mathrm{O}_{2}$ Exposure on miRNA and $m R N A$ Expression Profiles. Cells were grown to $90 \%$ confluency in $75 \mathrm{~cm}^{2}$ flasks and exposed to $25 \mu \mathrm{M} \mathrm{H}_{2} \mathrm{O}_{2}$ (equivalent to $5 \%$ of the $\mathrm{IC}_{50}$ ) in complete medium for $4 \mathrm{~h}$. Total RNA was isolated using the Qiagen miRNEasy Mini Kit and quality/ quantity was measured in the Molecular Genomics Core at UTMB. RNA was quantitated spectrophotometrically using a NanoDrop ND-1000 (NanoDrop Technologies, DE). Quality of the purified RNA was assessed by visualization of $18 \mathrm{~S}$ and 28S RNA bands using an Agilent Bioanalyzer 2100 (Agilent Technologies, CA). Resulting electropherograms were used in the calculation of the $28 \mathrm{~S} / 18 \mathrm{~S}$ ratio and the RNA Integrity Number. Reverse transcription was carried out using either the miScript II RT kit or $\mathrm{RT}^{2}$ First Strand and subsequent SYBR green based real-time PCR on a Bio-Rad Chromo4 Real-Time PCR Detector per the manufacturer's recommendation. The miRNA profile screening was performed using miScript Human miRNome PCR Array (MIHS-3216Z, Qiagen, Valencia, CA). RT ${ }^{2}$ Profiler Human Preeclampsia PCR Array (PAHS-163Z, Qiagen, Valencia, CA) was used for gene expression profiling. Data was analyzed using the $\Delta \Delta \mathrm{CT}$ method with either the miScript miRNA PCR Array Data Analysis version 3.5 or with the $\mathrm{RT}^{2}$ Profiler PCR Array Data Analysis (SABiosciences, Valencia, CA).

\section{Results}

3.1. $\mathrm{H}_{2} \mathrm{O}_{2}$-Induced Cytotoxicity in Villous $3 \mathrm{~A}$ Trophoblasts. In order to determine the appropriate $\mathrm{H}_{2} \mathrm{O}_{2}$ concentration for 

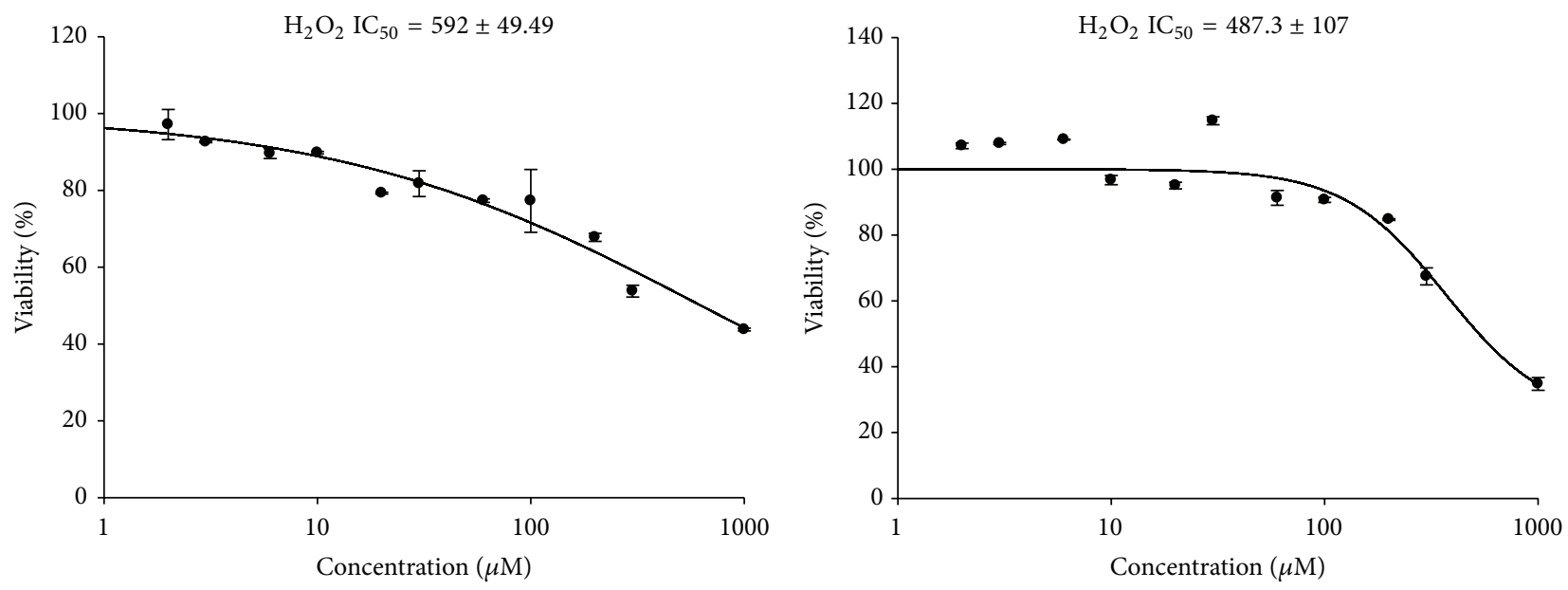

(a) 30 min exposure
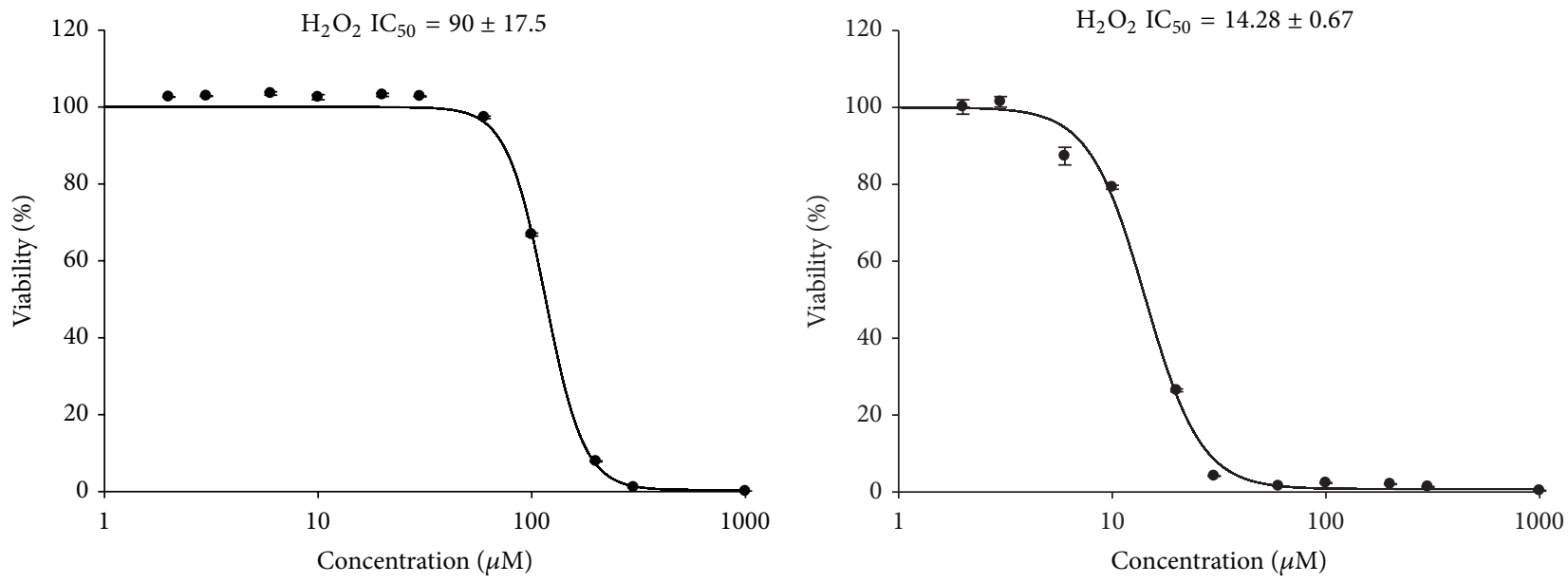

(c) $24 \mathrm{~h}$ exposure

(d) $48 \mathrm{~h}$ exposure

FIGURE 1: $\mathrm{IC}_{50}$ calculation for $\mathrm{H}_{2} \mathrm{O}_{2}$ after $30 \mathrm{~min}, 4 \mathrm{~h}, 24 \mathrm{hr}$, or $48 \mathrm{hr}$ in villous $3 \mathrm{~A}$ trophoblasts: $3 \mathrm{~A}$ cells were exposed to varying concentrations $(0,2,3,6,10,20,30,60,100,200,300$, and $1000 \mu \mathrm{M})$ of $\mathrm{H}_{2} \mathrm{O}_{2}$ and $\mathrm{IC}_{50}$ determined using the SRB assay. Data represent $n=3$ for each time point and concentration. IC $_{50}$ was calculated using SigmaPlot v12.3.

further experiments, cells were exposed to varying micromolar concentrations of $\mathrm{H}_{2} \mathrm{O}_{2}$ in complete medium for up to $48 \mathrm{~h}$ and cytotoxicity was determined using the SRB assay. Exposure of $3 \mathrm{~A}$ placental cells to $\mathrm{H}_{2} \mathrm{O}_{2}$ resulted in a time- and concentration-dependent cytotoxic effect. The $\mathrm{IC}_{50}$ values for $\mathrm{H}_{2} \mathrm{O}_{2}$ were 592, 487, 90, and $15 \mu \mathrm{M}$ after $30 \mathrm{~min}, 4,24$, and $48 \mathrm{~h}$ exposures, respectively (Figure 1). A concentration equivalent to $5 \%$ of the $\mathrm{IC}_{50}$ concentration was used for the miRNAs and mRNA expression profiling experiments. The 4hour exposure was selected for short-term exposure studies of the effect of $\mathrm{H}_{2} \mathrm{O}_{2}$ on miRNA and mRNA expression profile. The levels of GSH as well as SOD activity were assessed after exposure of the cells to $25 \mu \mathrm{M} \mathrm{H}_{2} \mathrm{O}_{2}$ for $4 \mathrm{~h}$ as markers for oxidative stress status [22, 23]. GSH level in $\mathrm{H}_{2} \mathrm{O}_{2}$ challenged cells was significantly reduced by $30 \%$ (from $361.44 \pm 10.01 \mathrm{mg} / \mathrm{mg}$ protein in untreated cells to $251.35 \pm$ 39.23 in the treated cells; $P<0.01$ ). Similarly, SOD activity in cells exposed to $\mathrm{H}_{2} \mathrm{O}_{2}$ was significantly reduced by over $35 \%(208.9 \pm 5.12 \mathrm{U} / \mathrm{mg}$ protein in treated cells compared to $321.71 \pm 6.78$ in the untreated cells; $P<0.01$ ).
3.2. $\mathrm{H}_{2} \mathrm{O}_{2}$ Alters Normal miRNA Expression Profile in Villous $3 A$ Trophoblasts. To investigate the potential effect of oxidative stress on miRNA expression profile in villous $3 \mathrm{~A}$ trophoblasts, cells were exposed to $25 \mu \mathrm{M} \mathrm{H}_{2} \mathrm{O}_{2}$ for $4 \mathrm{~h}$ in complete medium and total RNA (including miRNA) was isolated using the Qiagen miRNeasy Mini Kit. The Qiagen v16 miRNA Array was used to evaluate the expression of 1008 miRNAs after $\mathrm{H}_{2} \mathrm{O}_{2}$ exposure compared to unexposed control. In our study, 417 miRNAs were not expressed (unevaluable) in the tested cell line. Out of the 591 evaluable miRNAs, 195 were up- or downregulated by at least twofold after $\mathrm{H}_{2} \mathrm{O}_{2}$ exposure (Supplemental Table 1 available online at http://dx.doi.org/ $10.1155 / 2015 / 257090)$. The majority of altered miRNAs (95.5\%) were upregulated by at least 2 -fold and only $4 \%$ were downregulated by at least 2-fold (Figure 2). Mir-21, -770, and -596 were downregulated by more than 5 -fold, while mir-3907 was downregulated by more than 50-fold. Mir-637, mir-1911, mir-26b, mir-615, let-7a, and let-7f were upregulated more than 50-fold (Supplemental Table 1). 


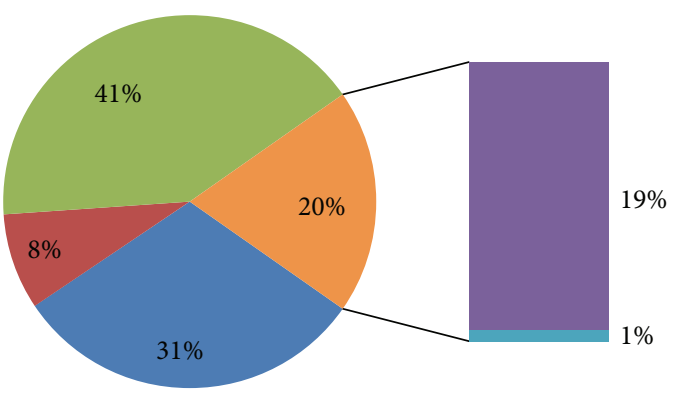

miRNA profiling

Changed $<2$-fold $\quad$ Downregulated
Upregulated
Unchanged

FIgURE 2: Pie chart representation for miRNome array results after $4 \mathrm{~h}$ exposure to $\mathrm{H}_{2} \mathrm{O}_{2}$ in villous $3 \mathrm{~A}$ trophoblasts.

TABLE 1: Clusters and families of miRNAs significantly altered by $\mathrm{H}_{2} \mathrm{O}_{2}$ in villous $3 \mathrm{~A}$ trophoblasts.

\begin{tabular}{lccc}
\hline & Count & Percent $^{\mathrm{b}}$ & $P$ value $^{\mathrm{c}}$ \\
\hline Cluster $^{\mathrm{a}}$ & & & \\
hsa-let-7e cluster & 3 & 100 & 0.0418 \\
hsa-let-106b cluster & 3 & 100 & 0.0418 \\
hsa-let-23b cluster & 3 & 100 & 0.0418 \\
Family $^{\mathrm{a}}$ & & & \\
let-7 family & 9 & 100 & $6.40 e-5$ \\
mir-15 family & 4 & 100 & 0.0144 \\
mir-17 family & 6 & 75 & 0.0237 \\
mir-181 family & 4 & 100 & 0.0144 \\
mir-29 family & 3 & 100 & 0.0418 \\
mir-329 family & 3 & 100 & 0.0418 \\
mir-368 family & 3 & 100 & 0.0418 \\
mir-99 family & 3 & 100 & 0.0418 \\
\hline
\end{tabular}

${ }^{a}$ Analysis of overexpressed miRNAs was performed by TAM (tool for annotations of miRNAs, version 2). Size of miRNA category was set as 1-100.

${ }^{b}$ Percent of miRNA changed between treated and controls cells within the cluster or family.

${ }^{c} P<0.05$ indicates a significant number of miRNAs altered within a cluster/family.

Using TAM (tool for annotations of microRNAs, version 2; http://202.38.126.151/hmdd/tools/tam.html/) analysis, our data indicate that the altered miRNAs fall into 43 clusters and 34 families, with 41 functions identified. Three clusters of miRNAs were significantly altered $(P<0.05)$ after $4 \mathrm{~h}$ exposure to $25 \mu \mathrm{M} \mathrm{H}_{2} \mathrm{O}_{2}$ including hsa-let-7e, -let-106b, and let-23b clusters (Table 1). Eight miRNA families (let-7, mir-15, mir-17, mir-181, mir-29, mir-329, mir-368, and mir-99) were significantly altered $(P<0.05)$ after $\mathrm{H}_{2} \mathrm{O}_{2}$ challenge (Table 1 ). Significant alterations $(P<0.05)$ occurred after exposure to $\mathrm{H}_{2} \mathrm{O}_{2}$ in miRNAs involved in critical cellular functions such as angiogenesis, apoptosis, cell proliferation, epithelialmesenchymal transition, folliculogenesis, granulopoiesis, hormone regulation, human embryonic stem cell regulation, immune response, inflammation, anticell proliferation as
TABLE 2: Functional pathways regulated by miRNAs altered by $\mathrm{H}_{2} \mathrm{O}_{2}$ in villous $3 \mathrm{~A}$ trophoblasts.

\begin{tabular}{|c|c|c|c|}
\hline Function $^{\mathrm{a}}$ & Count & Percent $^{\mathrm{b}}$ & $P$ value $^{\mathrm{c}}$ \\
\hline Angiogenesis & 14 & 61 & $7.9 e-3$ \\
\hline Apoptosis & 22 & 56 & $3.10 e-3$ \\
\hline Bone regeneration & 17 & 61 & $3.41 e-3$ \\
\hline Cell cycle related & 29 & 50 & $7.50 e-3$ \\
\hline Cell proliferation & 16 & 62 & $3.76 e-3$ \\
\hline $\begin{array}{l}\text { Epithelial-mesenchymal } \\
\text { transition }\end{array}$ & 24 & 63 & $1.72 e-4$ \\
\hline Folliculogenesis & 7 & 100 & $5.67 e-4$ \\
\hline Granulopoiesis & 9 & 90 & $4.48 e-4$ \\
\hline Hormones regulation & 29 & 54 & $1.77 e-3$ \\
\hline $\begin{array}{l}\text { Human embryonic stem } \\
\text { cell (hESC) regulation }\end{array}$ & 36 & 51 & $1.80 e-3$ \\
\hline Immune response & 29 & 73 & $3.36 e-7$ \\
\hline Inflammation & 22 & 65 & $2.02 e-4$ \\
\hline Adipocyte differentiation & 16 & 64 & $2.08 e-3$ \\
\hline Anticell proliferation & 11 & 100 & $1.07 e-6$ \\
\hline Brain development & 12 & 63 & $9.45 e-3$ \\
\hline Cell death & 31 & 62 & $2.54 e-5$ \\
\hline Cell division & 11 & 73 & $2.29 e-3$ \\
\hline Cell fate determination & 12 & 55 & 0.0415 \\
\hline Hematopoiesis & 18 & 62 & $1.77 e-3$ \\
\hline Lipid metabolism & 11 & 58 & 0.0304 \\
\hline miRNA tumor suppressors & 24 & 65 & $9.08 e-5$ \\
\hline Onco-miRNAs & 19 & 61 & $1.61 e-3$ \\
\hline
\end{tabular}

${ }^{a}$ Analysis of altered miRNAs was performed by TAM (tool for annotations of miRNAs, version 2). Size of miRNA category was set as 1-100.

${ }^{b}$ Percent of miRNA changed between treated and controls cells within a pathway/function.

${ }^{\mathrm{c}} P<0.05$ indicates a significant number of miRNAs altered within a pathway/function.

well as miRNA tumor suppressors, and onco-miRNAs which can affect cell proliferation and invasion (Table 2). Notably, 21 out of $30(70 \%)$ of evaluable miRNAs of the maternally imprinted miRNA cluster on chromosome 14 (C14MC) that is predominantly expressed in placenta and developing embryonic tissues were altered. Expression of the paternally imprinted chromosome 19 cluster (C19MC) was too low to be evaluated in this study.

3.3. $\mathrm{H}_{2} \mathrm{O}_{2}$ Alters mRNA Expression in Villous $3 A$ Trophoblasts. In order to investigate the effect of oxidative stress on mRNA expression profile, we determined mRNA expression levels of 84 genes potentially involved in preeclamptic pregnancies. Villous $3 \mathrm{~A}$ cells were mock-exposed in complete medium or exposed to $25 \mu \mathrm{M} \mathrm{H}_{2} \mathrm{O}_{2}$ in complete medium for 4 hours and total RNA was isolated using the Qiagen miRNeasy Mini Kit. The Qiagen $\mathrm{RT}^{2}$ Preeclampsia Array was used to evaluate the expression of these 84 genes after $\mathrm{H}_{2} \mathrm{O}_{2}$ exposure. As shown in Figure 3, of these 84 genes, 22 were up- or downregulated by at least twofold after $\mathrm{H}_{2} \mathrm{O}_{2}$ exposure. Of these, only 


\begin{tabular}{|c|c|c|c|c|c|c|c|c|c|c|c|c|}
\hline Layout & 1 & 2 & 3 & 4 & 5 & 6 & 7 & 8 & 9 & 10 & 11 & 12 \\
\hline A & $\begin{array}{c}\mathrm{ABCC} 1 \\
1.46\end{array}$ & $\begin{array}{c}\text { ABCG2 } \\
-1.58\end{array}$ & $\begin{array}{l}\text { ADM } \\
-1.07\end{array}$ & $\begin{array}{c}\text { AGTR1 } \\
-1.01\end{array}$ & $\begin{array}{c}\text { ANGPT2 } \\
-2.49\end{array}$ & $\begin{array}{l}\text { APLN } \\
-1.87\end{array}$ & $\begin{array}{l}\text { ATP1B1 } \\
1.96\end{array}$ & $\begin{array}{c}\text { ATP2A2 } \\
1.89\end{array}$ & $\begin{array}{c}\text { BCL6 } \\
1.34\end{array}$ & $\begin{array}{c}\text { BHLHE40 } \\
-1.04\end{array}$ & $\begin{array}{c}\text { C3 } \\
-1.25\end{array}$ & $\begin{array}{c}\text { CAV1 } \\
-1.4\end{array}$ \\
\hline B & $\begin{array}{l}\text { CCL2 } \\
-2.38\end{array}$ & $\begin{array}{c}\text { CD40LG } \\
-2.21\end{array}$ & $\begin{array}{l}\text { CDH13 } \\
-1.35\end{array}$ & $\begin{array}{c}\text { CFD } \\
-1.71\end{array}$ & $\begin{array}{l}\text { CLU } \\
1.05\end{array}$ & $\begin{array}{c}\text { COL14A1 } \\
-1.94\end{array}$ & $\begin{array}{c}\mathrm{CP} \\
-2.27\end{array}$ & $\begin{array}{l}\text { CRH } \\
-2.1\end{array}$ & $\begin{array}{c}\text { CRHBP } \\
1.24\end{array}$ & $\begin{array}{c}\text { CXCL10 } \\
-1.87\end{array}$ & $\begin{array}{c}\text { CXCL9 } \\
-1.62\end{array}$ & $\begin{array}{c}\text { CYP26A1 } \\
-1.87\end{array}$ \\
\hline $\mathrm{C}$ & $\begin{array}{c}\mathrm{DCN} \\
-2\end{array}$ & $\begin{array}{c}\text { DUSP1 } \\
1.64\end{array}$ & $\begin{array}{c}\text { EDN1 } \\
1.01\end{array}$ & $\begin{array}{c}\text { ENG } \\
1.19\end{array}$ & $\begin{array}{c}\text { F5 } \\
-1.87\end{array}$ & $\begin{array}{c}\text { FABP4 } \\
-1.7\end{array}$ & $\begin{array}{l}\text { FLT1 } \\
1.62\end{array}$ & $\begin{array}{l}\text { FLT4 } \\
-1.69\end{array}$ & $\begin{array}{c}\text { FSTL3 } \\
-1.61\end{array}$ & $\begin{array}{c}\text { HBEGF } \\
5.76\end{array}$ & $\begin{array}{c}\text { HGF } \\
-1.94\end{array}$ & $\begin{array}{c}\text { HIF1A } \\
1.57\end{array}$ \\
\hline $\mathrm{D}$ & $\begin{array}{c}\text { HLA-G } \\
-1.37\end{array}$ & $\begin{array}{c}\mathrm{HP} \\
-2.41\end{array}$ & $\begin{array}{c}\text { HSD17B1 } \\
-1.87\end{array}$ & $\begin{array}{c}\text { HSP90AA1 } \\
1.38\end{array}$ & $\begin{array}{l}\text { HTR3A } \\
-1.8\end{array}$ & $\begin{array}{l}\text { HTRA1 } \\
-1.06\end{array}$ & $\begin{array}{l}\text { IFNG } \\
-1.87\end{array}$ & $\begin{array}{c}\text { IGF1 } \\
-2.6\end{array}$ & $\begin{array}{c}\text { IGFBP3 } \\
1.07\end{array}$ & $\begin{array}{c}\text { IL10 } \\
-1.18\end{array}$ & $\begin{array}{c}\text { IL11 } \\
-1.63\end{array}$ & $\begin{array}{c}\text { IL15 } \\
-1.38\end{array}$ \\
\hline $\mathrm{E}$ & $\begin{array}{c}\text { IL18 } \\
-2.64\end{array}$ & $\begin{array}{l}\text { IL1A } \\
-2.07\end{array}$ & $\begin{array}{c}\text { IL2 } \\
-1.87\end{array}$ & $\begin{array}{c}\text { IL6 } \\
-2.02\end{array}$ & $\begin{array}{c}\text { IL8 } \\
-1.64\end{array}$ & $\begin{array}{l}\text { INHA } \\
-1.87\end{array}$ & $\begin{array}{c}\text { INHBA } \\
-1.04\end{array}$ & $\begin{array}{c}\text { ITGB3 } \\
-1.98\end{array}$ & $\begin{array}{c}\mathrm{KIT} \\
-1.22\end{array}$ & $\begin{array}{c}\text { KRT19 } \\
-1.87\end{array}$ & $\begin{array}{c}\text { LEP } \\
-8.42\end{array}$ & $\begin{array}{c}\text { LPL } \\
-2.22\end{array}$ \\
\hline $\mathrm{F}$ & $\begin{array}{c}\text { MAS1 } \\
-1.87\end{array}$ & $\begin{array}{c}\text { MMP12 } \\
-1.8\end{array}$ & $\begin{array}{c}\text { MMP9 } \\
-2.07\end{array}$ & $\begin{array}{c}\text { NCAM1 } \\
-1.42\end{array}$ & $\begin{array}{c}\text { NDRG1 } \\
-2.59\end{array}$ & $\begin{array}{l}\text { NOS3 } \\
-1.76\end{array}$ & $\begin{array}{c}\text { NTRK2 } \\
-2.67\end{array}$ & $\begin{array}{c}\text { PAPPA2 } \\
-2.31\end{array}$ & $\begin{array}{c}\text { PDGFD } \\
-1.87\end{array}$ & $\begin{array}{l}\text { PGF } \\
1.21\end{array}$ & $\begin{array}{c}\text { PGR } \\
-1.87\end{array}$ & $\begin{array}{l}\text { QPCT } \\
-2.54\end{array}$ \\
\hline G & $\begin{array}{c}\text { SERPINA3 } \\
-2.17\end{array}$ & $\begin{array}{c}\text { SOD1 } \\
-1\end{array}$ & $\begin{array}{l}\text { SPP1 } \\
-1.64\end{array}$ & $\begin{array}{l}\text { STAT1 } \\
-1.08\end{array}$ & $\begin{array}{l}\text { TAC1 } \\
-2.54\end{array}$ & $\begin{array}{l}\text { TAC3 } \\
-1.87\end{array}$ & $\begin{array}{c}\text { TEK } \\
-1.87\end{array}$ & $\begin{array}{c}\text { TGFB1 } \\
1.26\end{array}$ & $\begin{array}{c}\text { TNF } \\
-5.13\end{array}$ & $\begin{array}{c}\text { TREM1 } \\
-1.71\end{array}$ & $\begin{array}{l}\text { VCAN } \\
-1.87\end{array}$ & $\begin{array}{c}\text { VEGFA } \\
1.22\end{array}$ \\
\hline
\end{tabular}

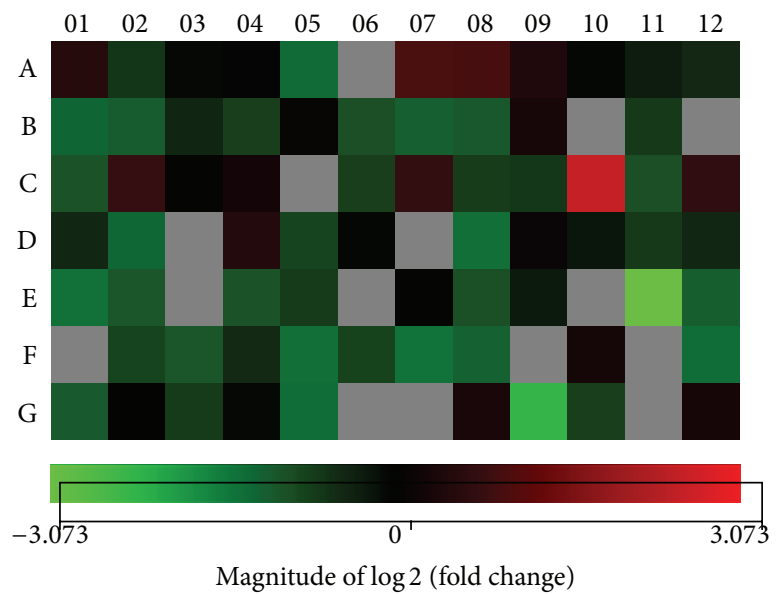

FiguRE 3: Heat map representation for the differential expression of genes associated with PE after 4 h exposure to $\mathrm{H}_{2} \mathrm{O}_{2}$ in villous $3 \mathrm{~A}$ trophoblasts. Gene expression is represented in the heat map in the color scale of $-3.073-3.073$ in green-red color scheme $(n=2)$. Genes evaluated and their locations on the heat map are depicted in the associated table above the heat map.

the HBEGF gene was found to be upregulated while the other 21 genes were downregulated (Table 3 ).

We used the Qiagen online $\mathrm{RT}^{2}$ Profiler PCR Array Data Analysis v3.5 to determine the correlation between the altered miRNAs and mRNAs in our study. Our analysis indicates that 53 of the overexpressed miRNAs in our study putatively target 11 of the downregulated genes (Table 4).

\section{Discussion}

In the current study, $\mathrm{H}_{2} \mathrm{O}_{2}$ exerted a cytotoxic effect in $3 \mathrm{~A}$ trophoblasts in a concentration- and time-dependent manner. These data are consistent with previous reports [5, 26]. However, the median inhibitory concentration $\left(\mathrm{IC}_{50}\right)$ of $\mathrm{H}_{2} \mathrm{O}_{2}$ in our study after $48 \mathrm{~h}$ exposure was $15 \mu \mathrm{M}$ which is 10 times lower than the $\mathrm{IC}_{50}$ reported by Zhou et al. using HTR-8/SVneo cells [5]. In a separate study, Moll et al. [26] used $\mathrm{H}_{2} \mathrm{O}_{2}$ concentrations up to $1000 \mu \mathrm{M}$, which is 66 times higher than our $\mathrm{IC}_{50}$ concentration, to evaluate apoptosis and proliferation in human term placentas. Murata et al. [27] used a concentration of $100 \mu \mathrm{M} \mathrm{H}_{2} \mathrm{O}_{2}$ to determine apoptotic and invasion rates in term extravillous trophoblasts at 24 hours. This concentration is comparable to our $\mathrm{IC}_{50}$ of $90 \mu \mathrm{M}$ at 24 hours. This variability in results can be attributed to the variation in sensitivity of the cells studied to determine $\mathrm{H}_{2} \mathrm{O}_{2}$ toxic effects. The villous trophoblast cell line $3 \mathrm{~A}$ used in our study, which is a first trimester placental cell line, seems to be more sensitive to $\mathrm{H}_{2} \mathrm{O}_{2}$ damage compared to HTR-8/SVneo cells or term primary cells used in these investigations $[5,26]$. Our studies were carried out using $5 \%$ of the $\mathrm{IC}_{50}$ of $\mathrm{H}_{2} \mathrm{O}_{2}(25 \mu \mathrm{M}$ at $4 \mathrm{~h})$ which is a subcytotoxic concentration. This level of exposure was chosen to mimic $\mathrm{H}_{2} \mathrm{O}_{2}$ concentration in $\mathrm{PE}$ placentas previously reported by Zhou et al. [5]. Given the reported duplicitous nature of ROS depending on their levels [28], we evaluated the oxidative stress status of the cells at this exposure level by assessing GSH level and SOD activity in the challenged cells as markers of oxidative stress $[22,23]$. Both GSH and SOD are of major importance in intracellular redox regulation [29, 30]. Our results revealed a significant reduction in GSH level and SOD activity indicating oxidative stress at this exposure level.

Reports indicate that miRNAs regulate migration, invasion, apoptosis, and proliferation of trophoblasts as well as angiogenesis within the placenta, although the functions of only a few miRNAs have been characterized [18]. Expression changes of miRNAs that regulate these functions have been reported in PE. Wang et al. [20] demonstrated an increase in $\mathrm{miR}-17,-20 \mathrm{a}$, and $-20 \mathrm{~b}$ in PE. These miRNAs target 
TABLE 3: mRNAs altered by at least twofold after $4 \mathrm{~h} \mathrm{H}_{2} \mathrm{O}_{2}$ exposure in villous $3 \mathrm{~A}$ trophoblasts.

\begin{tabular}{|c|c|c|}
\hline Gene symbol & Gene description & Fold change $^{\mathrm{b}}$ \\
\hline HBEGF $^{\mathrm{a}}$ & Heparin-binding EGF-like growth factor & 5.7637 \\
\hline ANGPT2 & Angiopoietin 2 & -2.4932 \\
\hline CCL2 & Chemokine (C-C motif) ligand 2 & -2.3834 \\
\hline CD40LG & CD40 ligand & -2.2084 \\
\hline $\mathrm{CP}$ & Ceruloplasmin (ferroxidase) & -2.2705 \\
\hline $\mathrm{CRH}$ & Corticotropin releasing hormone & -2.1038 \\
\hline $\mathrm{DCN}$ & Decorin & -2.0042 \\
\hline HP & Haptoglobin & -2.4083 \\
\hline IGF1 & Insulin-like growth factor 1 (somatomedin C) & -2.5991 \\
\hline IL18 & Interleukin 18 (interferon-gamma-inducing factor) & -2.6445 \\
\hline IL1A & Interleukin 1 , alpha & -2.0748 \\
\hline IL6 & Interleukin 6 (interferon, beta 2) & -2.0181 \\
\hline LEP & Leptin & -8.4152 \\
\hline LPL & Lipoprotein lipase & -2.2238 \\
\hline MMP9 & Matrix metallopeptidase 9 (gelatinase B, $92 \mathrm{kDa}$ gelatinase, $92 \mathrm{kDa}$ type IV collagenase) & -2.0748 \\
\hline NDRG1 & N-myc downstream regulated 1 & -2.5901 \\
\hline NTRK2 & Neurotrophic tyrosine kinase, receptor, type 2 & -2.6721 \\
\hline PAPPA2 & Pappalysin 2 & -2.3102 \\
\hline QPCT & Glutaminyl-peptide cyclotransferase & -2.5368 \\
\hline SERPINA3 & Serpin peptidase inhibitor, clade A (alpha-1 antiproteinase, antitrypsin), member 3 & -2.1705 \\
\hline TAC1 & Tachykinin, precursor 1 & -2.5368 \\
\hline TNF & Tumor necrosis factor & -5.1266 \\
\hline
\end{tabular}

${ }^{a}$ Upregulated gene is in bold font.

${ }^{\mathrm{b}}$ Fold change in $\mathrm{H}_{2} \mathrm{O}_{2}$ treated cells compared to nontreated control.

the angiogenesis factors EPHB4 and ephrin-B2 and could be responsible for the decreases in angiogenesis seen in $\mathrm{PE}$ [20]. Upregulation of miR-29b results in increased apoptosis with a corresponding decrease in invasion and angiogenesis in trophoblast cells [31]. MiR-155 targets cyclin D1 and the angiogenic regulating factor CYR61; both are downregulated in PE $[32,33]$. Overexpression of miR-210 in extravillous trophoblasts in culture results in decreased cell invasion [34]. MiR-376c, which is lower in both placenta and serum of preeclamptic women, reduces protein levels of ALK5 and ALK7, thus increasing cell proliferation [35].

In our study, after $4 \mathrm{~h}$ of $\mathrm{H}_{2} \mathrm{O}_{2}$ exposure, expression of 195 of evaluable miRNAs $(\mathrm{CT}<35)$ was altered by at least twofold. Of these, only seven were downregulated. We chose to focus on the short-term exposure to $\mathrm{H}_{2} \mathrm{O}_{2}$ for the determination of miRNA profile as other studies show a rapid $(<4 \mathrm{~h})$ miRNA expression response and subsequent downregulation of protein targets [36]. Our data are in partial agreement with published studies that examined miRNA changes in PE, with some conflicts. There were 6 miRNAs reported to be either up- or downregulated in PE that were not altered in our system. These include miR-210 [37], -34a [38], -149 [19], -19b [39], -92b, and -197 [17]. Two miRNAs, miR-194 and 195, were upregulated in our system in contrast to reported downregulation in the literature $[19,40]$. The discrepancy in results is not surprising since most studies were conducted on term placental tissue while we used a first trimester cytotrophoblast cell line. Expressions of placental miRNAs are known to be cell- and trimester-specific [14, 41]. In addition, PE often occurs concurrently with IUGR (intrauterine grown restriction) and preterm labor, both of which have their own miRNA pattern which can thus produce conflicting data. The placental mammal specific miRNA cluster on chromosome 14 (C14MC) predominantly expressed in placenta and embryonic tissues and maternally imprinted had 21 out of 30 (70\%) of evaluable miRNAs altered in our study. Meanwhile, expression of the paternally imprinted C19MC cluster was not detected. This expression pattern is in agreement with that found by Morales-Prieto et al. [14], showing higher expression of the $\mathrm{C} 14$ cluster in the first trimester with very little expression of C19 miRNAs. Although there are some data indicating an increase in C19MC miRNAs in PE, this increase is most likely due to a loss of methylation as this miRNA cluster is paternally imprinted [15]. Evidence suggests that hypomethylation of multiple genes contributes to early onset $\mathrm{PE}$ [42]. Data is mostly lacking for the role of the C14MC cluster in PE. MiR-483-5p was not altered while miR-377 was significantly upregulated in one study of preeclamptic women [16]. Yet, neither of these miRNAs could be evaluated in our study due to the high cycle number in our assay (CT > 35).

The expression profile of 84 genes known or suspected to be altered in PE was examined in this study (Figure 3). These genes are involved in different pathways including pregnancy maintenance, oxidative stress, hormones, growth factors, endothelial cell signaling, and signal transduction. As shown in Table 3, of these 84 genes, 22 were up- or downregulated 
TABLE 4: Altered miRNAs with putative altered mRNAs targets after $4 \mathrm{~h}$ exposure to $\mathrm{H}_{2} \mathrm{O}_{2}$ in villous $3 \mathrm{~A}$ trophoblasts.

\begin{tabular}{|c|c|c|c|c|}
\hline miRNA name & $\begin{array}{c}\text { Number of genes } \\
\text { targeted by this miRNA }\end{array}$ & $\begin{array}{l}\text { Number of target sites } \\
\text { identified in target genes }\end{array}$ & Range of strength scores ${ }^{\mathrm{a}}$ & Target genes \\
\hline hsa-miR-181a-5p & 3 & 3 & -0.4593 to -0.234 & DCN, IL1A, TNF \\
\hline hsa-miR-181c-5p & 3 & 3 & -0.4573 to -0.219 & DCN, IL1A, TNF \\
\hline hsa-miR-181b-5p & 3 & 3 & -0.4593 to -0.234 & DCN, IL1A, TNF \\
\hline hsa-miR-181d-5p & 3 & 3 & -0.4573 to -0.234 & DCN, IL1A, TNF \\
\hline hsa-miR-27b-3p & 3 & 3 & -0.203 to -0.0872 & IGF1, LEP, LPL \\
\hline hsa-miR-29a-3p & 3 & 4 & -0.4102 to -0.094 & IGF1, LEP, LPL \\
\hline hsa-miR-29c-3p & 3 & 4 & -0.4102 to -0.09 & IGF1, LEP, LPL \\
\hline hsa-miR-875-3p & 3 & 4 & -0.504 to -0.2443 & CD40LG, NDRG1, TNF \\
\hline hsa-miR-9-5p & 3 & 3 & -0.453 to -0.0467 & IGF1, LEP, NDRG1 \\
\hline hsa-miR-454-3p & 2 & 3 & -0.3152 to -0.219 & IGF1, TNF \\
\hline hsa-miR-543 & 2 & 2 & -0.39 to -0.259 & ANGPT2, IL1A \\
\hline hsa-miR-30e-5p & 2 & 2 & -0.452 to -0.1342 & IGF1, IL1A \\
\hline hsa-miR-30b-5p & 2 & 2 & -0.452 to -0.1236 & IGF1, IL1A \\
\hline hsa-miR-30a-5p & 2 & 2 & -0.452 to -0.1342 & IGF1, IL1A \\
\hline hsa-miR-30c-5p & 2 & 2 & -0.452 to -0.1236 & IGF1, IL1A \\
\hline hsa-miR-30d-5p & 2 & 2 & -0.452 to -0.1342 & IGF1, IL1A \\
\hline hsa-miR-424-5p & 1 & 1 & -0.0766 to -0.0766 & IGF1 \\
\hline hsa-miR-152-3p & 1 & 1 & -0.3972 to -0.3972 & IGF1 \\
\hline hsa-miR-148b-3p & 1 & 1 & -0.3972 to -0.3972 & IGF1 \\
\hline hsa-miR-425-5p & 1 & 1 & -0.4961 to -0.4961 & IGF1 \\
\hline hsa-miR-16-5p & 1 & 1 & -0.0977 to -0.0977 & IGF1 \\
\hline hsa-miR-497-5p & 1 & 1 & -0.0766 to -0.0766 & IGF1 \\
\hline hsa-miR-490-5p & 1 & 1 & -0.197 to -0.197 & NTRK2 \\
\hline hsa-miR-193a-5p & 1 & 1 & -0.115 to -0.115 & NTRK2 \\
\hline hsa-miR-15la-5p & 1 & 1 & -0.401 to -0.401 & NTRK2 \\
\hline hsa-miR-330-3p & 1 & 2 & -0.05 to -0.01 & NTRK2 \\
\hline hsa-miR-17-5p & 1 & 2 & -0.149 to -0.148 & NTRK2 \\
\hline hsa-miR-1271-5p & 1 & 1 & -0.108 to -0.108 & NDRG1 \\
\hline hsa-miR-20a-5p & 1 & 2 & -0.17 to -0.148 & NTRK2 \\
\hline hsa-miR-154-5p & 1 & 1 & -0.263 to -0.263 & NTRK2 \\
\hline hsa-miR-26b-5p & 1 & 1 & -0.1205 to -0.1205 & IGF1 \\
\hline hsa-miR-766-3p & 1 & 1 & -0.161 to -0.161 & IGF1 \\
\hline hsa-miR-190a-5p & 1 & 1 & -0.1862 to -0.1862 & IGF1 \\
\hline hsa-miR-452-5p & 1 & 1 & -0.3111 to -0.3111 & IGF1 \\
\hline hsa-miR-320a & 1 & 1 & -0.1466 to -0.1466 & IGF1 \\
\hline hsa-miR-320b & 1 & 1 & -0.1466 to -0.1466 & IGF1 \\
\hline hsa-miR-18b-5p & 1 & 1 & -0.2185 to -0.2185 & IGF1 \\
\hline hsa-miR-374a-5p & 1 & 1 & -0.511 to -0.511 & CCL2 \\
\hline hsa-miR-26a-5p & 1 & 1 & -0.105 to -0.105 & IGF1 \\
\hline hsa-miR-222-3p & 1 & 1 & -0.1612 to -0.1612 & IGF1 \\
\hline hsa-miR-221-3p & 1 & 1 & -0.1612 to -0.1612 & IGF1 \\
\hline hsa-miR-192-5p & 1 & 1 & -0.2211 to -0.2211 & IGF1 \\
\hline hsa-miR-196a-5p & 1 & 1 & -0.0267 to -0.0267 & IGF1 \\
\hline hsa-let-7f-5p & 1 & 1 & -0.1633 to -0.1633 & IGF1 \\
\hline hsa-let-7a-5p & 1 & 1 & -0.1592 to -0.1592 & IGF1 \\
\hline
\end{tabular}


TABLE 4: Continued.

\begin{tabular}{|c|c|c|c|c|}
\hline miRNA name & $\begin{array}{c}\text { Number of genes } \\
\text { targeted by this miRNA }\end{array}$ & $\begin{array}{l}\text { Number of target sites } \\
\text { identified in target genes }\end{array}$ & Range of strength scores ${ }^{\mathrm{a}}$ & Target genes \\
\hline hsa-miR-196b-5p & 1 & 1 & -0.0267 to -0.0267 & IGF1 \\
\hline hsa-let-7b-5p & 1 & 1 & -0.1592 to -0.1592 & IGF1 \\
\hline hsa-let-7i-5p & 1 & 1 & -0.1592 to -0.1592 & IGF1 \\
\hline hsa-let-7e-5p & 1 & 1 & -0.1592 to -0.1592 & IGF1 \\
\hline hsa-let-7d-5p & 1 & 1 & -0.1612 to -0.1612 & IGF1 \\
\hline hsa-let-7c-5p & 1 & 1 & -0.1592 to -0.1592 & IGF1 \\
\hline hsa-let-7g-5p & 1 & 1 & -0.1592 to -0.1592 & IGF1 \\
\hline hsa-miR-576-5p & 1 & 1 & -0.1892 to -0.1892 & IGF1 \\
\hline
\end{tabular}

${ }^{a}$ Strength scores are the $Z$ scores derived from the TargetScan algorithm. A more negative number indicates a stronger score and an increased likelihood that the gene is a bona fide target for the miRNA evaluated.

by at least twofold after $\mathrm{H}_{2} \mathrm{O}_{2}$ exposure. While it is difficult to provide mechanistic explanations to all changes observed in the expression profiles of the 22 genes, it is possible to provide some explanations based on the putative function of these genes in PE and through the correlation of our miRNA and mRNA data. For example, expression of Heparin-binding EGF-like growth factor (HBEGF) was upregulated by 5.8fold in cells challenged with $\mathrm{H}_{2} \mathrm{O}_{2}$. HBEGF is expressed in both villous and extravillous trophoblasts through the first trimester [43] and is known to act as a survival factor that hampers apoptosis [44] triggered by oxidative stress or other factors $[26,45]$. Therefore, its induction under the current experimental conditions could be a cellular defense against oxidative stress known to be associated with PE.

Our data showed that the expression of monocyte chemoattractant protein-1 (CCL2) was downregulated, while the expression of its putative regulator mir-374a-5p was upregulated. CCL2 is known to be expressed in first trimester trophoblasts [46] and is responsible for the activation and recruitment of macrophages to the developing placenta to aid in tissue remodeling after implantation [47]. The expression of CCL2 in first trimester trophoblasts was reported to be regulated by tumor necrosis factor (TNF- $\alpha$ ) [48]. In our study, expression level of TNF- $\alpha$ was also downregulated as was angiopoietin-2 (ANGPT2) when exposed to increased oxidative stress. ANGPT2 is crucial in regulating vascular remodeling through its interaction with endothelial cell Tie-2 receptor [49]. The levels of ANGPT2 were found to be lower in PE compared to normal pregnancy [50]. Similarly, we found the insulin-like growth factor-1 (IGF-1) expression to be decreased. IGF-1 was reported to be decreased in placental tissues from women suffering PE [51]. Of note is that 38 miRNAs that putatively regulate IGF-1 (Table 4) were upregulated in our study. The pregnancy-associated plasma protein A2 (PAPPA2) is an insulin-like growth factor-binding protein (IGFBP) protease expressed at high levels in the placenta. Increased levels of PAPPA2 in PE suggest a compensatory response to abnormal placentation, which might increase insulin-like growth factor (IGF) availability and promote fetoplacental growth [52]. However, PAPPA2 was downregulated in our study, which might also explain the observed reduction in IGF-1 expression in the current work.
The levels of matrix metalloproteinase-9 (MMP9) were decreased in trophoblast cells exposed to $\mathrm{H}_{2} \mathrm{O}_{2}$. MMP9 is an important factor for extracellular matrix remodeling and is responsible for the invasiveness of trophoblasts [53]. Its deficiency induced phenotypic changes that mimic PE in mice [54] and its levels are reduced in pregnancies complicated with PE [55]. Moreover, the level of corticotrophin releasing hormone (CRH) was also downregulated by $\mathrm{H}_{2} \mathrm{O}_{2}$ stress. CRH is released by trophoblasts to promote embryo implantation [56].

Leptin (LEP) gene expression was downregulated in our study. In silico analysis predicted the LEP to be a target of four miRNAs (mir-27b-3p, mir-29a-3p, mir-29c-3p, and mir-9-5p; Table 4). All of those miRNAs were overexpressed under the current experimental conditions. Our findings contrast other reports indicating that LEP is overexpressed in placental tissues at term in PE [57]. It should be noted however that most published data is derived from studies of term trophoblasts or placental tissues while our study focuses on first trimester trophoblasts, which mimics the early stage of pregnancy. This can explain some of the discrepancies in gene expression data observed between our study and others.

Our study has some limitations which we acknowledge. We examined only short-term effects of high $\mathrm{H}_{2} \mathrm{O}_{2}$ exposure on cell viability and short-term effects of low $\mathrm{H}_{2} \mathrm{O}_{2}$ exposure on miRNA and mRNA gene expression profiles. Gene expression changes can differ due to hypoxic versus normal growth conditions or short- versus long-term exposure. This study focuses only on short-term exposure and cytotoxicity due to the reported rapid changes in miRNA expression after initial exposure [36] but will be expanded in the future to include long-term genetic changes. In addition, a change in miRNA or mRNA expression does not necessarily lead to a change in encoded protein levels, protein modification, or protein function. Such information would be generated from specifically designed studies based on our findings. Lastly, we are using an SV40-transformed first trimester cell line rather than primary cells or choriocarcinoma cancer cells, which, to our knowledge, is one of the best available models for studies such as ours. Although the in vitro approach provides conformity of cell type over multiple experiments, in vitro response to ROS may not totally mimic the in vivo response. 
In summary, our data indicate that short-term exposure of $3 \mathrm{~A}$ villous first trimester trophoblasts to $\mathrm{H}_{2} \mathrm{O}_{2}$ significantly alters miRNA profile and mRNA expression of genes implicated in defective placental development. Our data, which indicate that oxidative stress alters miRNAs and RNAs expression, could partially explain some of the early changes in gene expression profiles and miRNA observed in PE.

\section{Conflict of Interests}

The authors declare that there is no conflict of interests regarding the publication of this paper.

\section{Authors' Contribution}

Courtney E. Cross and Mai F. Tolba contributed equally to this paper.

\section{Acknowledgments}

This work was supported by the National Institute of Environmental Health Sciences (T32ES007254 to Courtney E. Cross and Catherine M. Rondelli) and the John Sealy Memorial Endowment Fund for Biomedical Research. Additional support was provided by the NIEHS Center in Environmental Toxicology at the University of Texas Medical Branch funded through P30 ES006676.

\section{References}

[1] E. A. P. Steegers, P. von Dadelszen, J. J. Duvekot, and R. Pijnenborg, "Pre-eclampsia," The Lancet, vol. 376, no. 9741, pp. 631$644,2010$.

[2] E. A. Veal, A. M. Day, and B. A. Morgan, "Hydrogen peroxide sensing and signaling," Molecular Cell, vol. 26, no. 1, pp. 1-14, 2007.

[3] M. Emberton, G. L. Andriole, J. de La Rosette et al., "Benign prostatic hyperplasia: a progressive disease of aging men," Urology, vol. 61, no. 2, pp. 267-273, 2003.

[4] M. S. Steiner and S. Raghow, "Antiestrogens and selective estrogen receptor modulators reduce prostate cancer risk," World Journal of Urology, vol. 21, no. 1, pp. 31-36, 2003.

[5] X. Zhou, G.-Y. Zhang, J. Wang, S.-L. Lu, J. Cao, and L.-Z. Sun, "A novel bridge between oxidative stress and immunity: the interaction between hydrogen peroxide and human leukocyte antigen $\mathrm{G}$ in placental trophoblasts during preeclampsia," The American Journal of Obstetrics and Gynecology, vol. 206, no. 5, pp. 447.e7-447.e16, 2012.

[6] G. S. Prins and K. S. Korach, "The role of estrogens and estrogen receptors in normal prostate growth and disease," Steroids, vol. 73, no. 3, pp. 233-244, 2008.

[7] G. P. Risbridger, J. J. Bianco, S. J. Ellem, and S. J. McPherson, "Oestrogens and prostate cancer," Endocrine-Related Cancer, vol. 10, no. 2, pp. 187-191, 2003.

[8] Q. Wu, J. Shi, L. Chen et al., "Regulation of proliferation and differentiation of prostatic stromal cells by oestradiol through prostatic epithelial cells in a paracrine manner," $B J U$ International, vol. 101, no. 4, pp. 497-502, 2008.
[9] G. S. Prins, L. Birch, W. Y. Tang, and S.-M. Ho, "Developmental estrogen exposures predispose to prostate carcinogenesis with aging," Reproductive Toxicology, vol. 23, no. 3, pp. 374-382, 2007.

[10] A. B. Wallis, A. F. Saftlas, J. Hsia, and H. K. Atrash, "Secular trends in the rates of preeclampsia, eclampsia, and gestational hypertension, United States, 1987-2004," The American Journal of Hypertension, vol. 21, no. 5, pp. 521-526, 2008.

[11] R. I. Gregory, T. P. Chendrimada, and R. Shiekhattar, "MicroRNA biogenesis: isolation and characterization of the microprocessor complex," Methods in Molecular Biology, vol. 342, pp. 33-47, 2006.

[12] L. He and G. J. Hannon, "MicroRNAs: small RNAs with a big role in gene regulation," Nature Reviews Genetics, vol. 5, no. 7, pp. 522-531, 2004.

[13] J.-F. Mouillet, T. Chu, and Y. Sadovsky, "Expression patterns of placental microRNAs," Birth Defects Research, Part A-Clinical and Molecular Teratology, vol. 91, no. 8, pp. 737-743, 2011.

[14] D. M. Morales-Prieto, W. Chaiwangyen, S. Ospina-Prieto et al., "MicroRNA expression profiles of trophoblastic cells," Placenta, vol. 33, no. 9, pp. 725-734, 2012.

[15] S. Buckberry, T. Bianco-Miotto, and C. T. Roberts, "Imprinted and X-linked non-coding RNAs as potential regulators of human placental function," Epigenetics, vol. 9, no. 1, pp. 81-89, 2014.

[16] K. Mayor-Lynn, T. Toloubeydokhti, A. C. Cruz, and N. Chegini, "Expression profile of microRNAs and mRNAs in human placentas from pregnancies complicated by preeclampsia and preterm labor," Reproductive Sciences, vol. 18, no. 1, pp. 46-56, 2011.

[17] S.-Y. Choi, J. Yun, O.-J. Lee et al., "MicroRNA expression profiles in placenta with severe preeclampsia using a PNA-based microarray," Placenta, vol. 34, no. 9, pp. 799-804, 2013.

[18] G. Fu, J. Brkić, H. Hayder, and C. Peng, "MicroRNAs in human placental development and pregnancy complications," International Journal of Molecular Sciences, vol. 14, no. 3, pp. 5519-5544, 2013.

[19] L. Guo, S. Q. Tsai, N. E. Hardison et al., "Differentially expressed microRNAs and affected biological pathways revealed by modulated modularity clustering (MMC) analysis of human preeclamptic and IUGR placentas," Placenta, vol. 34, no. 7, pp. 599-605, 2013.

[20] W. Wang, L. Feng, H. Zhang et al., "Preeclampsia up-regulates angiogenesis-associated microRNA (i.e., miR-17, -20a, and 20b) that target ephrin-B2 and EPHB4 in human placenta," The Journal of Clinical Endocrinology \& Metabolism, vol. 97, no. 6, pp. E1051-E1059, 2012.

[21] P. Skehan, R. Storeng, D. Scudiero et al., "New colorimetric cytotoxicity assay for anticancer-drug screening," Journal of the National Cancer Institute, vol. 82, no. 13, pp. 1107-1112, 1990.

[22] C. Monteiller, L. Tran, W. MacNee et al., "The pro-inflammatory effects of low-toxicity low-solubility particles, nanoparticles and fine particles, on epithelial cells in vitro: the role of surface area," Occupational and Environmental Medicine, vol. 64, no. 9, pp. 609-615, 2007.

[23] M. K. Kale, "Thyroid gland in free radical induced oxidative stress," in Free Radicals in Human Health and Disease, Springer, New Delhi, India, 2015.

[24] G. L. Ellman, “Tissue sulfhydryl groups", Archives of Biochemistry and Biophysics, vol. 82, no. 1, pp. 70-77, 1959.

[25] M. Nishikimi, N. A. Roa, and K. Yogi, "Measurement of superoxide dismutase," Biochemical and Biophysical Research Communications, vol. 46, p. 849, 1972. 
[26] S. J. Moll, C. J. P. Jones, I. P. Crocker, P. N. Baker, and A. E. P. Heazell, "Epidermal growth factor rescues trophoblast apoptosis induced by reactive oxygen species," Apoptosis, vol. 12, no. 9, pp. 1611-1622, 2007.

[27] M. Murata, K. Fukushima, T. Takao, H. Seki, S. Takeda, and N. Wake, "Oxidative stress produced by xanthine oxidase induces apoptosis in human extravillous trophoblast cells," The Journal of Reproduction and Development, vol. 59, no. 1, pp. 7-13, 2013.

[28] J. D. Lambeth and A. S. Neish, "Nox enzymes and new thinking on reactive oxygen: a double-edged sword revisited," Annual Review of Pathology, vol. 9, pp. 119-145, 2014.

[29] A. V. Peskin, "Cu,Zn-superoxide dismutase gene dosage and cell resistance to oxidative stress: a review," Bioscience Reports, vol. 17, no. 1, pp. 85-89, 1997.

[30] H. J. Forman, H. Zhang, and A. Rinna, "Glutathione: overview of its protective roles, measurement, and biosynthesis," Molecular Aspects of Medicine, vol. 30, no. 1-2, pp. 1-12, 2009.

[31] P. Li, W. Guo, L. Du et al., "MicroRNA-29b contributes to pre-eclampsia through its effects on apoptosis, invasion and angiogenesis of trophoblast cells," Clinical Science, vol. 124, no. 1, pp. 27-40, 2013.

[32] Y. Dai, Z. Qiu, Z. Diao et al., "MicroRNA-155 inhibits proliferation and migration of human extravillous trophoblast derived HTR-8/SVneo cells via down-regulating cyclin D1," Placenta, vol. 33, no. 10, pp. 824-829, 2012.

[33] Y. Zhang, Z. Diao, L. Su et al., "MicroRNA-155 contributes to preeclampsia by down-regulating CYR61," American Journal of Obstetrics \& Gynecology, vol. 202, no. 5, pp. 466.el-466.e7, 2010.

[34] L. Anton, A. O. Olarerin-George, N. Schwartz et al., "miR210 inhibits trophoblast invasion and is a serum biomarker for preeclampsia," The American Journal of Pathology, vol. 183, no. 5, pp. 1437-1445, 2013.

[35] G. Fu, G. Ye, L. Nadeem et al., "MicroRNA-376c impairs transforming growth factor- $\beta$ and nodal signaling to promote trophoblast cell proliferation and invasion," Hypertension, vol. 61, no. 4, pp. 864-872, 2013.

[36] L. S. Chan, P. Y. K. Yue, Y. Y. Wong, and R. N. S. Wong, "MicroRNA-15b contributes to ginsenoside-Rgl-induced angiogenesis through increased expression of VEGFR-2," Biochemical Pharmacology, vol. 86, no. 3, pp. 392-400, 2013.

[37] B. L. Pineles, R. Romero, D. Montenegro et al., "Distinct subsets of microRNAs are expressed differentially in the human placentas of patients with preeclampsia," American Journal of Obstetrics and Gynecology, vol. 196, no. 3, pp. 261.e1-261.e6, 2007.

[38] L. Doridot, D. Houry, H. Gaillard, S. T. Chelbi, S. Barbaux, and D. Vaiman, "miR-34A expression, epigenetic regulation, and function in human placental diseases," Epigenetics, vol. 9, no. 1, pp. 142-151, 2014.

[39] P. Kumar, Y. Luo, C. Tudela, J. M. Alexander, and C. R. Mendelson, "The c-myc-regulated microRNA-17 92 (mir-17 92) and miR-106a 363 clusters target hCYP19A1 and hGCM1 to inhibit human trophoblast differentiation," Molecular and Cellular Biology, vol. 33, no. 9, pp. 1782-1796, 2013.

[40] Y. Bai, W. Yang, H.-X. Yang et al., "Downregulated miR-195 detected in preeclamptic placenta affects trophoblast cell invasion via modulating ActRIIA expression," PLoS ONE, vol. 7, no. 6, Article ID e38875, 2012.

[41] D. Wang, W. Song, and Q. Na, “The emerging roles of placentaspecific microRNAs in regulating trophoblast proliferation during the first trimester," The Australian \& New Zealand Journal of Obstetrics \& Gynaecology, vol. 52, no. 6, pp. 565-570, 2012.
[42] J. D. Blair, R. K. C. Yuen, B. K. Lim, D. E. McFadden, P. von Dadelszen, and W. P. Robinson, "Widespread DNA hypomethylation at gene enhancer regions in placentas associated with early-onset pre-eclampsia," Molecular Human Reproduction, vol. 19, no. 10, pp. 697-708, 2013.

[43] R. E. Leach, R. Khalifa, N. D. Ramirez et al., "Multiple roles for heparin-binding epidermal growth factor-like growth factor are suggested by its cell-specific expression during the human endometrial cycle and early placentation," Journal of Clinical Endocrinology and Metabolism, vol. 84, no. 9, pp. 3355-3363, 1999.

[44] M. P. Michalsky, A. Kuhn, V. Mehta, and G. E. Besner, "Heparinbinding EGF-like growth factor decreases apoptosis in intestinal epithelial cells in vitro," Journal of Pediatric Surgery, vol. 36, no. 8, pp. 1130-1135, 2001.

[45] M. Mackova, R. T. Kilani, S. T. Davidge, and L. J. Guilbert, "The effect of oxygen tension on intracellular survival signalling in primary villous trophoblasts," Placenta, vol. 24, no. 6, pp. 627637, 2003.

[46] H. O. D. Critchley, R. L. Jones, R. G. Lea et al., "Role of inflammatory mediators in human endometrium during progesterone withdrawal and early pregnancy," Journal of Clinical Endocrinology and Metabolism, vol. 84, no. 1, pp. 240-248, 1999.

[47] V. M. Abrahams, Y. M. Kim, S. L. Straszewski, R. Romero, and G. Mor, "Macrophages and apoptotic cell clearance during pregnancy," American Journal of Reproductive Immunology, vol. 51, no. 4, pp. 275-282, 2004.

[48] C. J. Lockwood, P. Matta, G. Krikun et al., "Regulation of monocyte chemoattractant protein-1 expression by tumor necrosis factor-alpha and interleukin-1beta in first trimester human decidual cells: implications for preeclampsia," The American Journal of Pathology, vol. 168, no. 2, pp. 445-452, 2006.

[49] P. C. Maisonpierre, C. Suri, P. F. Jones et al., "Angiopoietin-2, a natural antagonist for Tie2 that disrupts in vivo angiogenesis," Science, vol. 277, no. 5322, pp. 55-60, 1997.

[50] E. G. Zhang, S. K. Smith, P. N. Baker, and D. S. Charnock-Jones, "The regulation and localization of angiopoietin-1, -2, and their receptor Tie2 in normal and pathologic human placentae," Molecular Medicine, vol. 7, no. 9, pp. 624-635, 2001.

[51] E. A. Dubova, K. A. Pavlov, V. M. Lyapin, G. V. Kulikova, A. I. Shchyogolev, and G. T. Sukhikh, "Expression of insulinlike growth factors in the placenta in preeclampsia," Bulletin of Experimental Biology and Medicine, vol. 157, no. 1, pp. 103-107, 2014.

[52] J. K. Christians and A. Gruslin, "Altered levels of insulin-like growth factor binding protein proteases in preeclampsia and intrauterine growth restriction," Prenatal Diagnosis, vol. 30, no. 9, pp. 815-820, 2010.

[53] Y. Yang, J. Zhang, Y. Gong et al., "Increased expression of prostasin contributes to early-onset severe preeclampsia through inhibiting trophoblast invasion," Journal of Perinatology, vol. 35, pp. 16-22, 2015.

[54] V. Plaks, J. Rinkenberger, J. Dai et al., "Matrix metalloproteinase-9 deficiency phenocopies features of preeclampsia and intrauterine growth restriction," Proceedings of the National Academy of Sciences of the United States of America, vol. 110, no. 27, pp. 11109-11114, 2013.

[55] C. H. Graham and K. R. McCrae, "Altered expression of gelatinase and surface-associated plasminogen activator activity by trophoblast cells isolated from placentas of preeclamptic patients," The American Journal of Obstetrics and Gynecology, vol. 175, no. 3, pp. 555-562, 1996. 
[56] A. M. Bamberger, V. Minas, S. N. Kalantaridou et al., "Corticotropin-releasing hormone modulates human trophoblast invasion through carcinoembryonic antigen-related cell adhesion molecule-1 regulation," The American Journal of Pathology, vol. 168, no. 1, pp. 141-150, 2006.

[57] V. Sitras, R. H. Paulssen, H. Grønaas et al., "Differential placental gene expression in severe preeclampsia," Placenta, vol. 30, no. 5, pp. 424-433, 2009. 

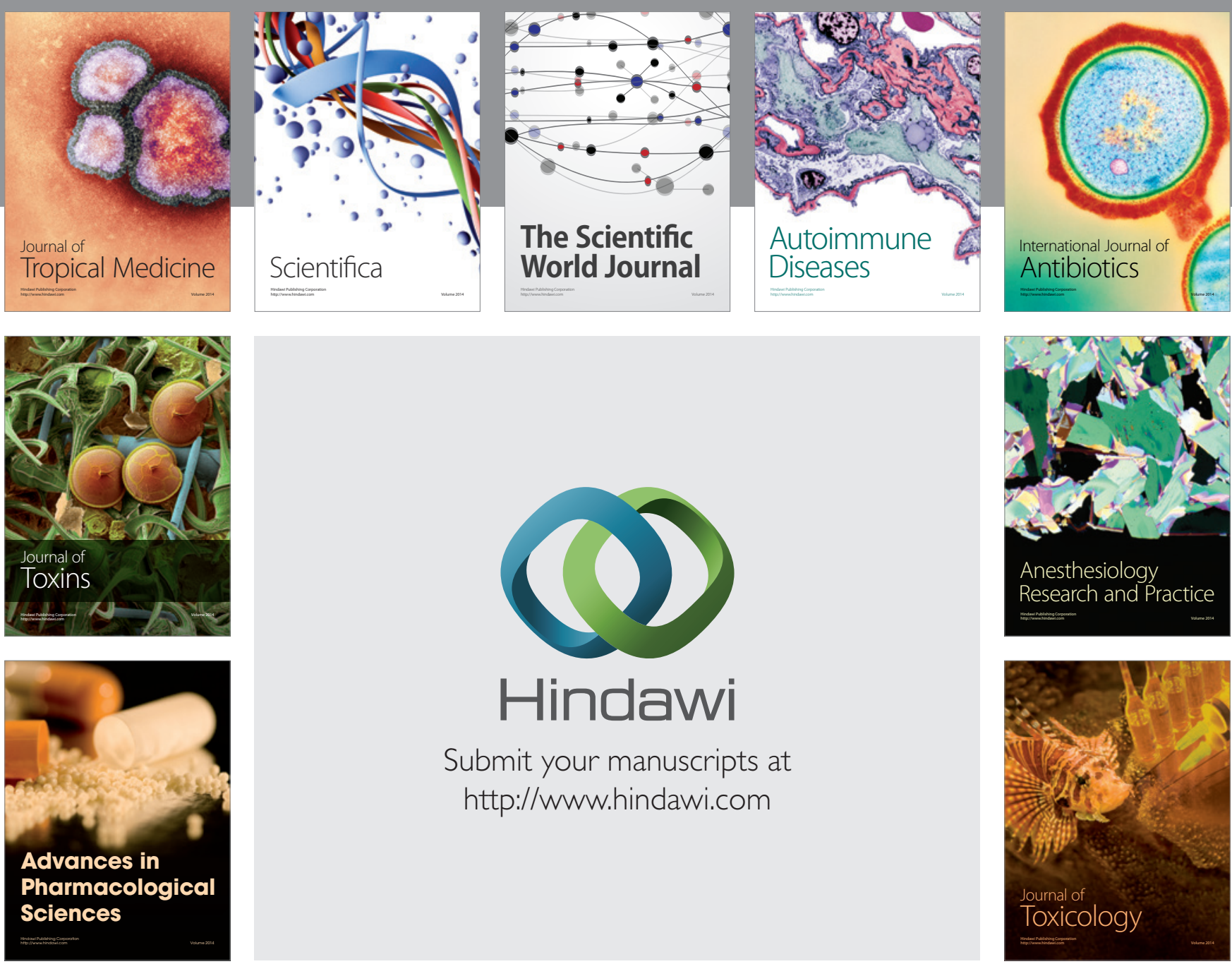

\section{Hindawi}

Submit your manuscripts at

http://www.hindawi.com
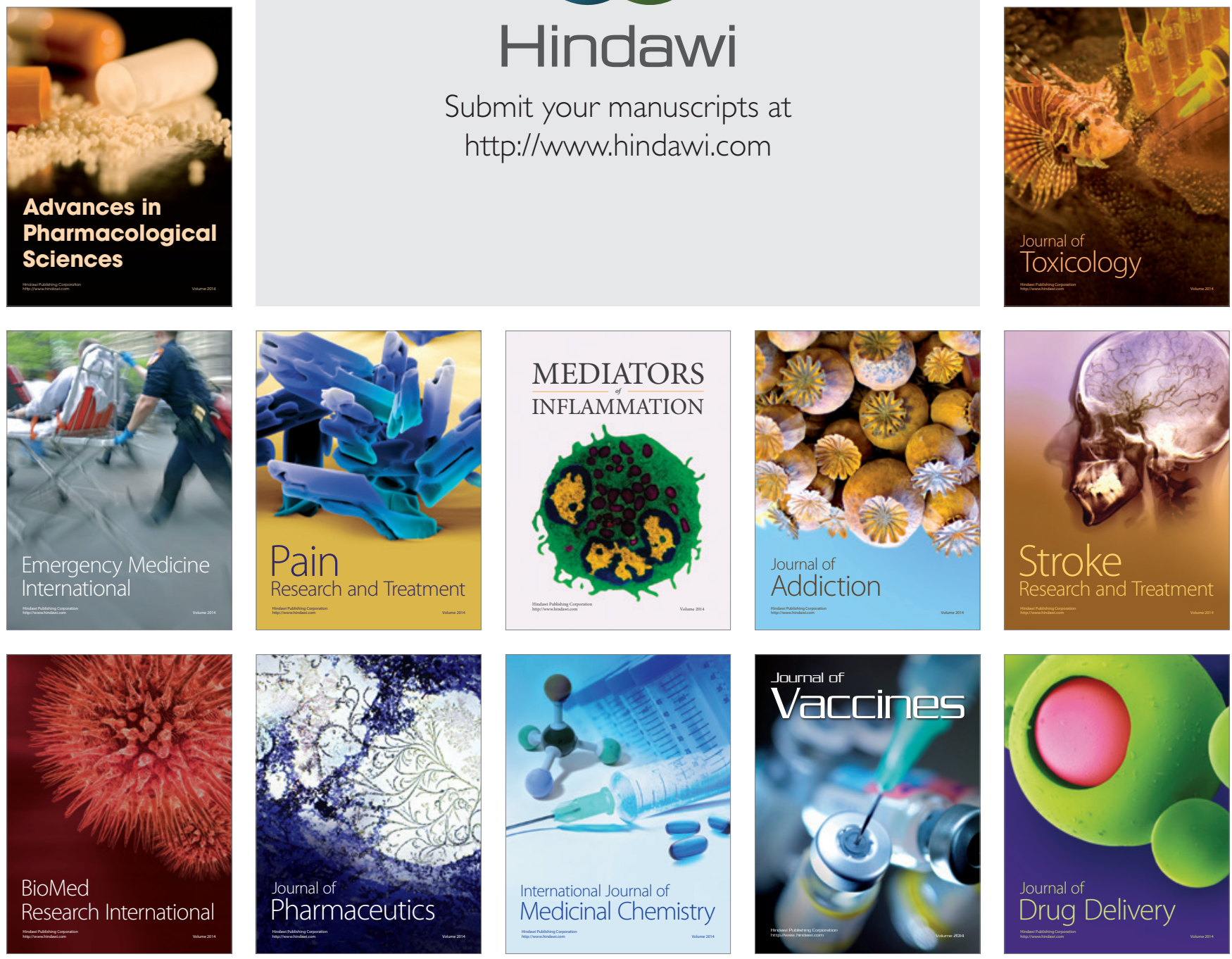